\title{
Generating situations of Moral Distress in Primary Care Nurses
}

\author{
Situações geradoras de Distresse Moral em enfermeiras da Atenção Primária \\ Situaciones generadoras de Distresse Moral en enfermeras de la Atención Primaria
}

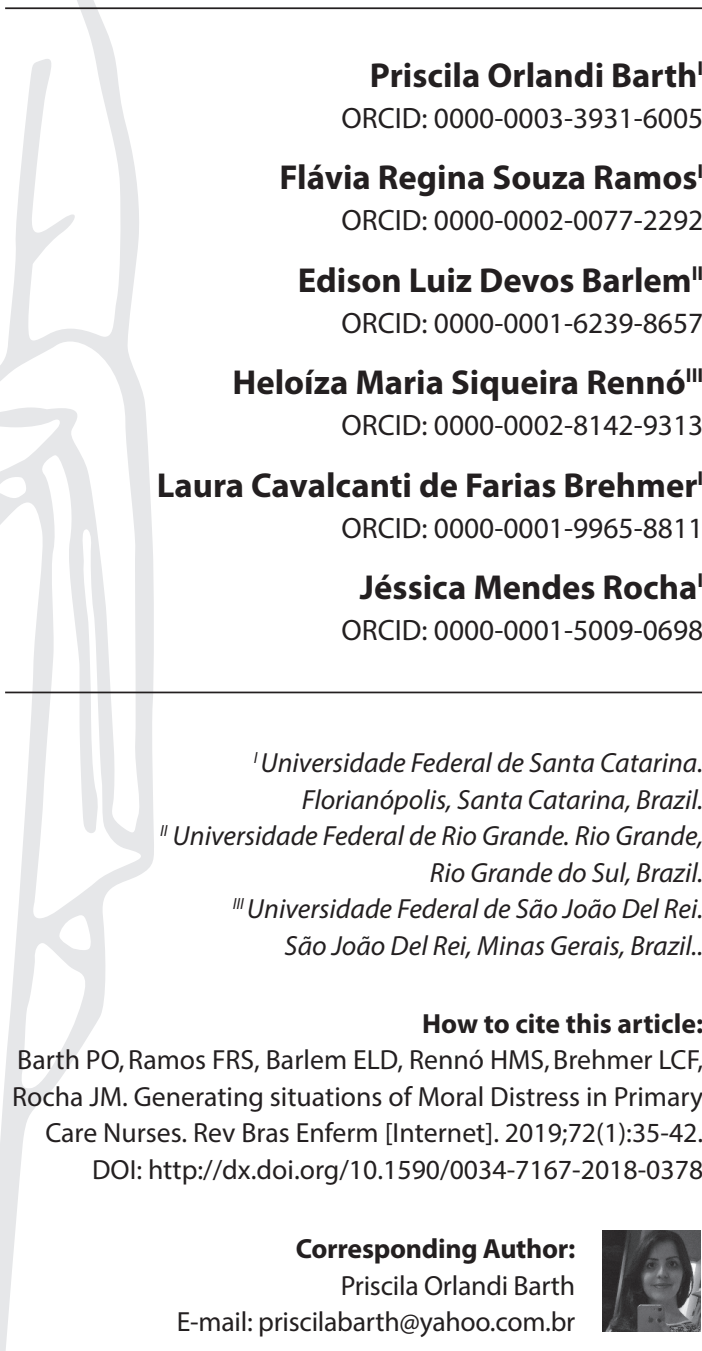

Submission: 06-02-2018

Approval: 07-17-2018

\begin{abstract}
Objective: To analyze the situations generating Moral Distress in Primary Care nurses from different regions of Brazil. Method: Qualitative research, with 13 nurses of the Brazilian Primary Health Care, through a semi-structured interview and submitted to the Discursive Textual Analysis, with the resources of the software ATLAS.ti 7.0. Results: They are presented in four categories, relating the Moral Distress to the professional; health services; users and conflicts in professional practice. Final considerations: By assuming ethical and political values as guides to their action, nurses give greater visibility to the moral content of many problems and weaknesses that could be seen only by the bias of working conditions.
\end{abstract}

Descriptors: Moral; Nurses; Primary Health Care; Working Conditions; Professional Exhaustion.

\section{RESUMO}

Objetivo: Analisar as situações geradoras de Distresse Moral em enfermeiras da Atenção Primária de diferentes regiões do Brasil. Método: Pesquisa qualitativa, com 13 enfermeiras da Atenção Primária à Saúde brasileira, por meio de entrevista semi-estruturada e submetidas à Análise Textual Discursiva, com os recursos do software ATLAS.ti 7.0. Resultados: Apresentam-se em quatro categorias, relacionando o Distresse Moral ao profissional; aos serviços de saúde; aos usuários e aos conflitos no exercício profissional. Considerações finais: Ao assumirem valores éticos e políticos como norteadores de sua ação, as enfermeiras dão maior visibilidade ao conteúdo moral de muitos problemas e fragilidades que poderiam ser vistas apenas pelo viés das condições de trabalho.

Descritores: Moral; Enfermeiras; Atenção Primária à Saúde; Condições de Trabalho; Esgotamento Profissional.

\section{RESUMEN}

Objetivo: Analizar las situaciones generadoras de Distresse Moral en enfermeras de la Atención Primaria de diferentes regiones de Brasil. Método: La investigación cualitativa, con 13 enfermeras de la Atención Primaria a la Salud brasileña, por medio de entrevista semi-estructurada y sometidas al Análisis textual Discursivo, con los recursos del software ATLAS.ti 7.0. Resultados: Se presentan en cuatro categorías, relacionando el Distresse Moral al profesional; a los servicios de salud; a los usuarios ya los conflictos en el ejercicio profesional. Consideraciones finales: Al asumir valores éticos y políticos como orientadores de su acción, las enfermeras dan mayor visibilidad al contenido moral de muchos problemas y fragilidades que podrían ser vistas sólo por el sesgo de las condiciones de trabajo.

Descriptores: Moral; Enfermeras; Atención Primaria de Salud; Condiciones de Trabajo; Agotamiento Profesional. 


\section{INTRODUCTION}

The pioneering concept of Moral Distress (MD) was presented as a psychological imbalance, caused by feelings of pain and anguish, when the professional knows what should be done, but due to institutional, interpersonal and interprofessional barriers, is prevented to exercise its function according to its moral precepts ${ }^{(1)}$.

This concept has been debated in the last 30 years in several studies; however, there are still gaps in the knowledge of reality and weaknesses of the concept itself. One of the criticisms that has been made is that the narratives of MD are seen as confused in the ethical dimensions of work in Nursing and the lack of depth of knowledge that encompasses the psychological and ethical foundations of the ethical issues faced by the nurse ${ }^{(2-3)}$.

There is a consensus that the MD runs through the emotional, physical and psychic of the nurse, from the constraints and constraints generated by the omission or failure to perform the appropriate action ${ }^{(4)}$. There is a consensus that the impotence or inability to perform the appropriate action is key elements for the onset of MD. Another outstanding aspect is the way each professional experiences the MD in the different work settings and levels of complexity, pointing to the need for new conceptual propositions that can support such an enterprise ${ }^{(5)}$.

With a new look, a Brazilian conceptual framework is presented, which points out the MD as a procedural phenomenon and at the same time a unique experience that integrates ethical and moral experience. In this approach, we have the productive sense of the MD by the aggregation of the experience of self in the constitution of the formation of the ethical subject ${ }^{(5)}$.

The MD as a construct encompasses, procedurally, elements that articulate ethical experience, such as moral problem, moral uncertainty, moral sensibility, moral restlessness, moral deliberation and professional ethical competencies. The moral problem is the starting point of the MD, because there is no MD without the subject being in front of a problem that demands positioning. For the problem to be perceptible it is necessary to have the moral sensitivity, a capacity for refinement, of differentiated perception ${ }^{(6)}$.

Given that each human being experiences the process of $M D$ in a unique and unique way, because it has different beliefs, values and cultures, the responses and consequences for the subject itself will also be diversified. In addition to leaving the profession, situations of professional isolation, mental disorders, physical and emotional exhaustion are reported ${ }^{(5)}$.

In Brazil, MD studies have been developed with some variations of approaches, such as bibliographic reviews, methodological studies, reflection, validation, quantitative research and qualitative research ${ }^{(3,5-10)}$. Thus, it is evident the importance of understanding the process of MD in the different contexts of the nurse's performance.

The studies presented in the international and national literature mostly portray MD in the hospital setting in its various areas

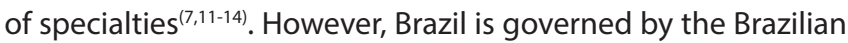
Unified Health System (SUS - Sistema Único de Saúde), which has in Primary Health Care its axis of the Health Care Networks (RAS Redes de Atenção à Saúde) and access to services. This is directed at local health needs, in which the nurse presents herself as a reference professional in the community and in health services.
Primary Care is governed by the Política Nacional de Atenção Básica (freely translated as National Primary Care Policy) established by Ordinance $48 / \mathrm{MoH} / 2006$, restructured by Ordinance $2.488 / \mathrm{MoH} / 2011 / 2012$ and currently by Ordinance 2,436 , dated September $21,2017^{(15)}$. The Primary Health Care (PHC) presented without distinction of concepts by Ordinance 2,436/2017 defines this as a set of actions that involves promotion, prevention, protection, diagnosis, treatment, rehabilitation, harm reduction, palliative care and surveillance in health, developed through integrated care practices and qualified management, carried out with a multiprofessional team and directed to the population in defined territory.

Since the first Ordinance in 2006, nurses' assignments can be considered sources of stress and/or distress in relation to professional responsibility, complexity and quantity of activities to be developed. The last Ordinance also moves in this direction, because it brings questionable attributions to the work of the nurse, such as supervising the work of the Community Health Agent, who can now carry out activities restricted to the nursing team, such as curative work, among others. Added to these attributions, we have several issues related to the precariousness of working conditions, problems related to management, users and teamwork. The demands and workloads, even if they become sources of stress, may or may not trigger distress or Moral Distress, since the latter indicates an impotence to act according to their moral judgment.

Given the breadth and specificity of this setting, as well as the nurse's primary role, it is necessary to investigate the MD process in this context.

\section{OBJECTIVE}

This study aims to analyze the generating situations of Moral Distress in Primary Care nurses from different regions of Brazil.

\section{METHOD}

\section{Ethical Aspects}

This research is linked to the macroproject entitled: O processo de angústia/sofrimento moral em Enfermeiras de diferentes contextos de trabalho em saúde, which was submitted to the Research Ethics Committees with Human Beings of the three Universities involved in the Multicentric Project, with the following final opinions: Universidade Federal de Santa Catarina, Universidade Federal de Minas Gerais and Universidade Federal de Rio Grande. It is worth noting that the guidelines established by Resolution $466 / 12$ of the Health Ethics Committee were followed, and that all nurses signed the ICT (Informed Consent Term). To maintain anonymity, the lines were identified by the letter $\mathrm{N}$, of nurse, with numerical sequence (N1, N2, N3...).

\section{Type of setting and study}

Exploratory descriptive qualitative research, developed in the context of the Brazilian Primary Care. According to data from the Cadastro Nacional dos Estabelecimentos de Saúde do Brasil (freely translated as National Registry of Health Establishments in Brazil) ${ }^{(16)}$, Brazil has 50,165 Primary Care teams, of which 18,407 are located in 
the Northeast region, 16,502 in the Southeast region, 7,315 in the South region, 4,460 in the region North and 3,481 in the Midwest, the number of Primary Care nurses is 59,036.

\section{Data source}

The study participants were 13 nurses working in Primary Care in Brazil, 3 of who were from the South, 3 from the Southeast, 3 from the Northeast, 2 from the North and 2 from the Center-West. As inclusion criterion was adopted the minimum performance of 6 months in Primary Care. It sought to have the representativity of at least 1 nurse from each region of Brazil, and the data collection was finalized when the process of data saturation began, that is, when the data began to repeat, bringing no new aspect the search.

The nurses were chosen intentionally by contact via e-mail and social networks, explaining about the research and inviting their participation. When there was a return for interest in participation, the Informed Consent Term (ICT) was sent via e-mail so that they could read and sign if they consented, and after being scanned, they were returned via e-mail to the researcher.

\section{Collection and organization of data}

The interviews followed the following script: 1. Presentation of the concept of MD to nurses; 2. Questionings: - from the concept exposed, what situations of MD do you live in your reality?; What feelings does this generate in you? How do you deal with these situations? In this study, only the first question regarding the triggering situations of MD is addressed. The interviews were conducted from January to March 2016, online via Skype, with the average time of 35 minutes, recorded digitally, transcribed in full and returned to the participants for validation of the final text.

\section{Data analysis}

In order to analyze the data, we used the textual Discursive Analysis (DA) reference ${ }^{(17)}$ in part, considering that the semantic analysis proposed by the authors was not part of this study, besides the support of the qualitative data analysis software Atlas.ti 7.0. The analysis unfolded in four stages: 1 ) disassembly of the texts (insertion of texts within the Hermeneutic Unit software). At that moment, the interviews were inserted into the software and a deep reading was carried out; 2 ) establishment of relations (insertion of codes - codes and quotations - selection of excerpts from interviews). In this step, the coding process begins, that is, the insertion of codes by themes or keywords in excerpts from the interviews; 3 ) capture of a new emergent (formulation of families- families/categories/ subcategories). At this stage, the grouping of codes occurs by theoretical and thematic agglutination, thus forming the families or initial categories of the analysis process; 4) re-localization of the findings in a self-organized process (formulation of networks/ main categories). Finally, the last analysis of the initial categories was carried out, restructured in networks, also by theoretical and thematic agglutination, building the central relations of the analysis process. Data analysis revealed four central categories: MD related to the professional; MD related to health services; MD related to users; and $M D$ related to conflicts in professional practice.

\section{RESULTS}

The research subjects were mostly female (nine), aged between 28 and 35 years, with an average time of five years of training, two participants had a master's degree and the other 11 had specialization in the area of Family Health.

\section{Moral Distress related to the professional}

The MD related to the professional contemplates issues such as: Work overload, professional stability, performance of the other's function, lack of continuity of care, lack of qualified professionals, lack of professional qualification (self) and lack of human resources.

Different aspects are interrelated, such as the overload of work and performance of the function of the other generated by insufficient quantitative or lack of qualified professionals, and often added to labor issues that lead to the lack of stability in employment. Thus, one factor conditions the other, in a multi-causal chain in the development of MD in the daily routine of nurses.

[...] the team was complete, there was a doctor, a dentist, but they were not $P C$-oriented, they were not interested in working at all, I started having a hard time developing my nurse work with this new team. (N5)

The PC is empty all the time, has no nurse, no doctor, no dentist, I even stayed three months without a doctor and two years without a dentist. In addition to not having all the professionals, you had to create criteria to solve that problem, alone. (N5)

Still related to the professional, stand out situations in which the performance of ethically appropriate action is hampered by the lack of qualification of the professional himself that defines such action as necessary for the continuity of care. Thus the perceived limitation is not by an external factor, but by a self-criticism. It is clear that the lack of qualification and continuity of care are often present through the expansion and restructuring of Primary Care, which demands from the professional new capacities in face of the diversity of health needs and demands.

Often, we feel insecure because it comes from a high-risk patient; I at least have no security, I feel disabled, because sometimes even had to whom to refer, but the professionals here are complicated, the area of health is complicated, the county does not counterpart on many things. (N7)

With the precepts of the Psychiatric Reform, we welcome all people within the Basic Health Units, including with mental suffering, alcoholism, drug users, but it is still difficult because we still do not have much preparation to receive and make a qualified listener, propose activities. (N3)

\section{Moral Distress related to health services}

The MD related to health services pointed to two sets of findings. The first is focused on limits located in the service, related to high demand as opposed to a series of shortages of physical structure, materials, equipment and human resources, which also end up generating work overload and compromises in the 
quality of care. A second set refers to deficiencies in the service network, involving flows between services, the operation of referral and counter-referral, and the rear that ensures continuity of care of greater complexity. Associated with such precariousness are criticisms and conflicts with local or municipal management, with institutional norms or governmental policies.

When addressing the large number of users and the lack of resources, from materials to professionals, a barrier is observed for the development of health actions in a resolute and humanized way.

Generally, we create this anguish by more structural problems. In my reality, there is lack of medication, lack of physical structure, $H R$, this ends up generating problems and stress with the users, much less in relation to the way the worker does his work. (N2)

I worked in an area with 5,000 people and there were basically two thousand without CHA coverage, not to mention that it was for me to have 8 CHA and I was working with 6, because many were removed by the union and did not send anyone to cover his area nor the of the other was far away because of illness, because she had a leprosy reaction, the sun exposure further affected her illness. (N5)

The lack of continuity of care, related to the problems related to reference and referral services and the organization of flows between these services was also cited as a factor in the development of the MD.

Ifyou say that it is an emergency appointment it has to be considered urgently, I cannot wait 3 months, I can wait at most 3 weeks, and this gives anguish to those who are there at the PONTA working. The regulation system is what causes me much revolt, in fact today is even more material, materials until they are already good in units, but regulation is still a knot in our life. Depending on what the user needs, you will be waiting a long time. (N4)

In relation to users is more the question of medium and high complexity. In Primary Care there is the impasse for the referral and this causes me impotence. (N7)

In Primary Care, structural and organizational barriers are viewed as routine, but difficult to resolve by professionals, because they are out of bounds or governability. There is a strong interrelationship between the factors identified with existing conflicts with management and with government policies and norms that, for different competencies, should support and guarantee the necessary conditions for the resolvability of care.

Moreover, regarding the issue of PC management, they knew of the problems there and did nothing about it, they would play to you, even mistreat you, because the professionals were angry. (N5)

According to the norm of epidemiological surveillance (influenza vaccine campaign), who has the right or not to take the vaccine by SUS for free [...] everyone is excited, everyone wants, except that we come with the norms of surveillance, we have to respect [...] The Health Office releases to make the vaccine in the Office X, for all the servants [...] I go unhappily comply with an order, I will not say that it generates a conflict, but it is something that I think is wrong, because we are denying the population, and have to go there, and it does not matter the technical note. (N1)
The nurses highlight the conflicts related to the political issues that affect the management. They denounce problems regarding the distribution and correct use of funds, the definition of priorities and political/private interests that prevail over the interests.

It is complicated, there are many procedures that you know what has to be done to the detriment of the political barrier, always have the politics, you have to deceive, invent and omit reality for the patients, even if it is not the right, this makes us frustrated, makes us want to leave. (N6)

Unfortunately, the big problem is the political issue, I' $m$ in the office, here comes my boss, talks to the mayor, there is the politics that is immense, and then she does what, cannot discount in my boss, I'll leave my staff, and this happens a lot, happens in all instances, in the Office, in the PSF, in the area of health in general, both hospital, and Primary Care. (N9)

Many of the factors referred to refer to the great regional inequalities involving the Brazilian Primary Care, which also express the unequal weight of "bad politics" and "mismanagement" on the organization of care, coverage, access and quality of care, so that the outstanding criticisms must be taken as a manifestation not generalizable.

\section{Moral Distress related to users}

The MD related to users is linked to situations of conflict, lack of continuity of care, violence in the community and social vulnerability. The conflict between the nurse and the user often arises from a professional's deliberation that considers valid principles, such as the right to information and protection versus the right to confidentiality. They may also be related to limitations in the supply and resolution of care, due to the lack of respect for the user's autonomy or obstacles in overcoming traditional forms of care and work organization.

We are following a pregnant woman and it has been detected that she is HIV positive in prenatal care, and she does not want to tell the partner, so you make every approach for her to speak, do what you think is right, but you have to respect her right not to disclose the diagnosis. I felt conflicted because the other is being put at risk. (N1)

We have resistance to patient adherence in some cases, not so much of the patient, but we deal with children who in the test of the foot have diagnosed some diseases, sickle cell anemia, hypothyroidism, cystic fibrosis, and sometimes the parents refuse. A husband did not want to let his mother accompany his son because of the driver's jealousy, for example, so we had to join the tutelary board, police, because the father would not accept the mother's travel with the child. (N6)

It is explicit that the nurse's performance in Primary Care is mediated by conflicting relationships and by the lack of subsidies for care delivery. These inconsistencies and instabilities in health practices are reflected in the inability to implement problemsolving and quality care.

In addition, issues related to violence and social vulnerabilities also imply impotence and, consequently, MD, at the moment when it becomes a barrier for the professional to develop the action that he believes to be correct or to achieve the desired results in that community. 
Sometimes we want to take action, especially in health education, in relation to the culture of peace, and we cannot develop for fear of trafficking, so there are subliminal messages for the team, do not go outside, in these territories you do not if they do, that kind of subject you do not work. The community itself comes and warns us, so that we do not enter into greater risks. (N2)

People suffer more from giving advice about care and they cannot develop it because they do not provide subsidies for this care. This causes an anguish that they cannot follow because they have poor social conditions and it makes them feel anguished. (N2)

The nurse must understand the needs of the user, act on them and maintain relationships of reciprocity and cooperation with the same. Such relationships can be permeated by difficulties and instabilities, which must be overcome through the support of the user and the community, under the risk of such actions being ineffective, harming not only the user but also the professional.

\section{Moral Distress related to conflicts in professional practice}

The MD related to conflicts in the professional practice encompasses the triggering factors represented by a conflict between the judgment and the personal conduct of the nurse with that of another professional, especially doctors and Community Health Agents (CHA).

Some conflicts, such as those related to the conduct itself, to the governmental norms and to the legislation that governs the profession are interconnected. When the practitioner judges his own conduct, even in the absence of a concrete act, but by the mere finding of a potential or effective limitation, he reflects critically on legislative and political issues that govern his work. The valorization of the accomplishment of goals and the quantitative collection of the actions by the management of the services, to the detriment of the quantitative aspects, is experienced in the routine work of the nurse.

I felt negligent. Even though he was already HIV positive, I think it was his right to know. So I felt very uncomfortable with this situation, having to obey a law. I did not reveal myself for fear of losing my COREN. (N1)

As soon as I assumed the team was almost to finish the deadline to register the children in the Bolsa Familia [Bolsa Familia is a social welfare program of the Brazilian government, part of the Fome Zero network of federal assistance programs]. I had to make a joint effort [...] I had to deal with the processes and delivered them, but I delivered them in a way that I know qualitatively that was not good, I did a quantitative aspect, but I did not evaluate all those real children, I did not understand all the vulnerabilities of that group, I simply weighed and I understood. (N4)

Due to the plurality of demands that Primary Care needs to respond to and the multiprofessional nature of health interventions, it is common to witness conflicts within the teams. Among these, we highlight the conflicts with the medical professional, regarding the hegemony of their knowledge and the disagreement regarding their conduct, when they are envisioned alternatives of action ethically more appropriate.

Some doctors tightened the agenda schedule only on the morning shift, attended 20 people and did not appear in the afternoon shift because they had already reached their goal [...] and a user arrived who was supposed to be served by him, and he refused, the NT gauged BP and was high and he was user of it. He said "no. I've already served my 20", and I, of course, was outraged. (N4)

Because the doctor is the boss, then you lose your autonomy as a professional. You try to work with a multiprofessional team, but cannot, makes it difficult to practice. If you had a team-wide involvement in deciding patient care, but the case is not even brought. (N8)

We think ethically, professionally, we study one thing and when it goes to practice, there are innumerable institutional barriers, barriers of the medical professional that is above, barriers of lack of respect of the colleague, even a nursing technician who does not learned to respect other people and he does not respect you either and then it becomes a mess. (N9)

The conflicts identified in the relations with the $\mathrm{CHA}$ refer to the lack of identification with the team, the non-recognition of the nurse's work, or even their important role within the community. Often, there is a lack of understanding of primary care objectives by the $\mathrm{CHA}$ themselves. Although the assignments of the $\mathrm{CHA}$ are legally established, they may be corrupted and not executed in their entirety.

I have a lot of trouble with the CHA, for example, we do a lot of things on Saturday morning, or after work hours, which is better for certain activities and I still find a lot of resistance. They think they have to work from 7 to 17 and that's it, and that their job is to do a home visit and that's it. So the promotion and other activities they think are not their jobs [...] I have been frustrated countless times trying to do some activity, a campaign. (N8)

Most of the time, we came across denunciations of the community that was not satisfied, and they complained at the unit, and realized that we had this point control, but when we went to search to see what they [CHA] were doing and they were not doing home visits, they were at home, or doing any other personal activity, different from what it was to be done there at that moment, and that although we had a formed team, with structure, we did not had effective action, and over time was getting frustrating. (N12)

The Brazilian health system has Primary Care as a reference for health actions, based on the resolution and the needs of users. However, as expressed by the findings, lack of resources, lack of organization and working conditions, conflicts with and between institutional, governmental, professional and personal policies are predominant factors of predisposition of the nurse to MD.

\section{DISCUSSION}

The results of this research point to several factors that trigger the nurse's MD, intrinsic to the professional's everyday life, such as lack of conditions and organization of the work process, conflicts in interpersonal relationships (user, community, health professionals) and conflicts related to management of services and the health system.

The lack of conditions and organization of work implies in the overload, high demand of users, lack of diverse resources, such as physical structure, medicines, human resources. It was also pointed 
out the lack of professional qualification and lack of continuity of care, which were presented in this study as MD factors.

These factors are also seen in other Primary Care studies as barriers for the nurse to develop effective action in health work, generating feelings of devaluation, uncertainty, impotence, dissatisfaction ${ }^{(18-20)}$.

In this study, work overload presents itself as a conditioning factor for MD at the moment it influences the planning and execution of health care. Some elements are also associated, such as the deficit of physical structures, high demand of users, failures in the networks of attention, dissatisfaction with salaries, excessive working hours, lack of human resources and excessive administrative activities ${ }^{(18)}$.

Another important factor for the effective professional exercise refers to the qualification of the nurse. In this qualification, the development of competence for ethical action is implicit, which has proved to be an important component in triggering MD. This is because, the exercise of ethical action provides questions, dilemmas and ethical conflicts regarding the performance of the team and the effectiveness of the actions carried out. It also interferes in the confrontation of these questions, when the limitation is perceived in itself or in another professional. Strategies, such as meetings among professionals, training, tools to evaluate ethical problems, help to promote ethical competence and can have positive effects in coping with and reducing the levels of Moral Distress in face of the ethical challenges present in the work reality of nurses ${ }^{(21)}$.

The practice of health care requires the qualification of the nurse for the exercise of ethical action. Nursing professionals need to look closely at what is presented as normal and question their institutions, interpersonal relationships, and themselves, identifying the reasons why situations become seemingly insurmountable obstacles, and even the reasons that lead them to $\mathrm{MD}^{(6)}$.

This ethical training should happen from Nursing training, with emphasis on the curricular stage, when the nursing student is faced with reality and ethical problems and dilemmas. During the formation process, the student can develop ethical skills and experience moral suffering ${ }^{(10)}$.

The finding of difficulties in the professional practice due to insufficient training should also mobilize processes of retraining, which would represent a coping and overcoming the cause of MD. However, it must be considered that the multifaceted needs of health and Primary Care continuously challenge the scope and sufficiency of knowledge and practices, since acting in a field without full control of all its complexity can lead to insecurity and stress.

In the work contexts, conflicts are experienced in personal and professional relationships, both user-professional and professional-professional. These conflicts are often linked to the lack of preparation of the professional, lack of dialogue, cooperation and integration, leading to discomfort, dissatisfaction, displeasure, weariness and lack of motivation ${ }^{(22-24)}$.

The conflicts with the users presented as an important factor in the development of the MD, mainly related to adherence to the nurse-directed conduct. In this case, sensitivity and moral reflection on a problem makes apprehensible the moral component that would otherwise be invisible in technical, political, and relational issues that are the basis for the MD process. The study of ethical problems is as important as the effects of these on different subjects. Descriptions of ethical problems with users refer to communication failures, disrespect for autonomy or disrespectful treatment of the user by the nurse.

The ethical problems in the relationships among the members of the team are due to the lack of commitment of some professionals, disrespect among them or the lack of preparation of the nurse to work in Primary Care ${ }^{(25)}$.

In addition, primary care specificities emerged in Brazil, not present in other MD studies, such as those pointed out to the conflicting relationships established between $\mathrm{CHA}$ and the nurse. The CHA is part of the community, has knowledge about its problems and existing vulnerability situations ${ }^{(26)}$. This professional may conflict with the nurse when she is forced to perform actions that are not part of her professional competence.

The fact that each professional responds ethically and legally for their acts in their respective oversight bodies contributes to the respect and respect of each member of the team; however, the $\mathrm{CHA}$ does not have a legal body to support it, leading to experiencing conflicts of this dimension ${ }^{(27)}$. These conflicting relationships tend to aggravate the new assignments proposed for CHA in Ordinance $2,436^{(15)}$, which adds previously exclusive activities of the nursing team.

Conflicting professional relationships that become "problematic" or object of moral judgment should only trigger MD in the nurse if its finding were accompanied by a real, if not insurmountable obstacle at least momentarily so perceived, in order to prevent ethically elected action correct. However, what emerges from the analysis is the predominance of problems and precariousness, such as those derived from inadequate working conditions, which if faced would not necessarily lead to MD, since an ethically acceptable decision/action can still be taken even in unfavorable settings in the face of serious precariousness. Obviously there will be wear and dissatisfaction, but a causal linearity of these with the MD should be carefully considered, including raising the possibility of limiting one's own understanding of the concept.

Issues related to management, norms and policies, that focus on work and services, articulate what has been categorized as both MD related to health services and conflicts in professional practice. The conflict is due to the recognition of unjust situations that obedience to the norm entails in managerial processes that are detrimental to daily work, established vertically, partially and not without personal interests. This does not consider that the prioritization and choices of a given health action to respond to one and not another person/ demand can already produce ethical differences and problems with management, directly influencing the nurse's experience of $\mathrm{MD}^{(9)}$.

There is a rupture between the right to health of the user, as set forth in the Brazilian Federal Constitution, and the way it applies in the reality of Health Care, especially between the mismatch between what is contractualized and the interactions between coordinators and workers, generating disagreements, discussions and emotional reactions ${ }^{(27)}$.

MD and ethical demand are very much present in nurses' work. To deal with these issues, practitioners use different coping resources, positive or negative. These resources can be positive and lead to dialogue and reflection, and can have negative effects when they lead the professional to accept and conform to reality. The isolated experience of ethical situations by the nurse, without support from colleagues or the institution, causes their moral suffering ${ }^{(21)}$. 
Thus, the issue of MD is related to the environment of the work situation, that is, it is not limited to individual actions, but to the needs of all staff and users.

\section{Study limitation}

Because this is a qualitative research, the study does not infer the generalization of the results, although it has sought to capture experiences of professionals in different realities of the country. Another limit is related to the very concept of MD and to the understanding of this by the professional, since there will always be a subjective component about what is posed as ethically correct action and that poses as a real impediment to such action.

\section{Contributions to Nursing}

The contribution of this study was made in pointing out some of the factors that trigger MD, such as the lack of working conditions and interpersonal conflicts, evidencing the relationship they present between work dissatisfaction and MD. From the identification of these, it is possible to propose coping strategies to the $M D$, eliminating or reducing their causal factors, as well as their consequences, such as the abandonment of the profession, stress, anxiety. Thus, the contribution of this study in the area of Nursing stands out, since its originality in Brazilian Primary Health Care.

\section{FINAL CONSIDERATIONS}

The factors conditioning the onset of MD in Primary Care nurse are part of the daily routine of this professional. Working conditions, the form of organization, professional and interpersonal relationships, the conflicts existing in these relations and the ways to manage Health Care are the triggers for the MD.

Health actions are interventions about need and demands, depending on how they are designed and how different actors and resources are organized to meet them. The commitment to the user and the quality desired for the care offered is shown as an ethical value to be defended, in the broader health setting, as a citizen's right. By assuming as a guiding force for their action, nurses give greater visibility to the moral content of many problems and weaknesses that might otherwise be seen only by the bias of working conditions.

It is important to emphasize that MD is still an incipient topic in the Brazilian setting, especially in Primary Care, and it is necessary to advance research in this particular setting so that strategies can be created to encourage them to cope. The forms of confronting and deliberating in relation to the identified sources of MD were not the object of this clipping, but it was evidenced the importance of the profession to develop in depth the diversity of manifestations of the MD in the diversified Brazilian context. As a pioneering study to focus the theme of MD in the specific context of Primary Care, the study presented a basis for understanding the complexity of this problem and indicative for both new studies and educational interventions to address its causes and consequences, promoting the necessary reflection professional ethics in this field.

\section{FUNDING}

This study was funded by the Conselho Nacional de Desenvolvimento Cientifico e Tecnológico (National Council for Scientific and Technological Development - CNPq).

\section{REFERENCES}

1. Jameton A. A reflection on moral distress in nursing together with a current application of the concept. J Bioeth Inq. 2013;10:(3):297-308. doi: 10.1007/s11673-013-9466-3

2. Johnstone, MJ, Hutchinson, A. Moral distress' - time to abandon a flawed nursing construct? Nurs Ethics. 2015; 22(1):5-14. doi: $10.1177 / 0969733013505312$

3. Ramos FRS, Barlem ELD, Brito MJM, Vargas MA, Schneider DG, Brehmer LCDF. Conceptual framework for the study of moral distress in nurses. Texto Contexto Enferm [Internet]. 2016 [cited 2018 May 05];25(2):e4460015. Available from: http://dx.doi. org/10.1590/0104-07072016004460015

4. McCarthy J, Gastmans, C. Moral distress: A review of the argument-based nursing ethics literature. Nurs Ethics. 2015;22(1):131-52. doi: $10.1177 / 0969733014557139$

5. Ramos FRS, Barth PO, Schneider AMM, Cabral AS, Reinaldo JS. Effects of moral distress on nurses: integrative literature review. Cogitare Enferm [Internet]. 2016 [cited 2018 Oct 31];21(2):1-13. Available from: doi: http://dx.doi.org/10.5380/ce.v21i2.45247

6. Barlem ELD, Ramos FRS. Constructing a theoretical model of moral distress. Nurs Ethics [Internet]. 2015;22(5):608-615. doi: $10.1177 / 0969733014551595$

7. Fruet IMA, Dalmolin GL, Speroni KS. [Moral distress assessment instruments to nursing workers: Integrative review]. Rev Enferm UFSM [Internet]. 2017 [cited 2018 Oct 31];7(2):314-26. Available from: http://dx.doi.org/10.5902/2179769220716 Portuguese

8. Ramos FRS, Barlem ELD, Brito MJM, Vargas MAO, Schneider DG, Brehmer LCF. Construction of the brazilian scale of moral distress in nurses - a methodological study. Texto Contexto Enferm [Internet]. 2017 [cited 2018 May 05];26(4):e0990017. Available from: http://dx.doi. org/10.1590/0104-07072017000990017

9. Barth PO, Ramos FRS, Barlem ELD, Dalmolin GL, Scheneider DG. Validation of a moral distress instrument in nurses of primary health care. Rev. Lat Am Enfermagem [Internet]. 2018 [cited 2018 Oct 31];26:e3010. doi: 10.1590/1518-8345.2227.3010 
10. Renno HMS, Ramos FRS, Brito MJM. Moral distress of nursing undergraduates: Myth or reality? Nurs Ethics [Internet]. 2016 [cited 2018 May 05];25(3):304-12. Available from: http://dx.doi.org/ 10.1177/0969733016643862

11. Barlem ELD, Lunardi VL, Lunardi GL, Tomaschewski-Barlem JG, Almeida ASH, Domingues C. Psycometric characteristics of the moral distress scale in brazilian nursing professionals. Texto Contexto Enferm [Internet]. 2014 [cited 2018 May 05];23(3):563-72. Available from: http:// dx.doi.org/10.1590/0104-07072014000060013

12. Barlem ELD, Lunardi VL, Lunardi GL, Dalmolin GL, Tomaschewski JG. The experience of moral distress in nursing: the nurses' perception. Rev Esc Enferm USP [Internet]. 2012 [cited 2018 May 06]; 46(3):678-85. Available from: http://dx.doi.org/10.1590/S0080-62342012000300021

13. Lusignani M, Gianni ML, Re LG, Buffon ML. Moral distress among nurses in medical, surgical and intensive-care units. J Nurs Manag [Internet]. 2016 [cited 2018 May 05];25(6):477-85. Available from: https://doi.org/10.1111/jonm.12431

14. O'Connell CB. Gender and the experience of moral distress in critical care nurses. Nurs Ethics [Internet]. 2015 [cited 2018 May 05];22(1):3242. Available from: https://doi.org/10.1177/0969733013513216

15. Ministério da Saúde (BR), Gabinete do Ministro. Portaria n 2.436, de 21 de Setembro de 2017. Aprova a Política Nacional de Atenção Básica, estabelecendo a revisão de diretrizes para a organização da Atenção Básica, no âmbito do Sistema Único de Saúde (SUS) [Internet]. Diário Oficial da União: República Federativa do Brasil; 2017 [cited 2018 May 05]. Sep 22. Seção 1: [about 5 screens]. Available from: http://bvsms. saude.gov.br/bvs/saudelegis/gm/2017/prt2436_22_09_2017.html

16. Cadastro Nacional de Estabelecimentos de Saúde (CNES) [Internet]. Ministério da Saúde: CNES; 2016 [cited 2018 may 05]. Available from: http://cnes.datasus.gov.br/

17. Moraes R, Galiazzi MC. [Discursdive textual analysis: a multiple face reconstructive process]. Cienc Educ [Internet]. 2006 [cited 2018 Nov 3];12(1):117-28. Available from: http://www.scielo.br/pdf/ciedu/v12n1/08 Portuguese.

18. Pires DEP, Machado RR, Soratto J, Scherer MA, Golçalves ASR, Trindade LL. Nursing workloads in family health: implications for universal access. Rev Lat Am Enfermagem [Internet]. 2016 [cited 2018 May 05];24:e2682:. Available from: doi: 10.1590/1518-8345.0992.2682

19. Matumoto S, Fortuna CM, Kawata LS, Mishima SM, Pereira MJB. Mapping pain in the clinical practice of nurses within primary health care. Texto Contexto Enferm [Internet]. 2013 [cited 2018 May 05];22(2):318-326. Available from: http://dx.doi.org/10.1590/ S0104-07072013000200007

20. Cordeiro TMSC, Araújo TM. [Prevalence of inadequate work ability among nursing workers in the primary care setting]. Rev Bras Med Trab [Internet]. 2017 [cited 2018 May 05];15(2):150-157. Available from: doi: 10.5327/Z1679443520177004 Portuguese.

21. Schaefer R, Vieira M. Ethical competence as a coping resource for moral distress in nursing. Text Context Nursing [Internet]. 2015 [cited 2018 May 06];24(2):563-573. Available from: http://dx.doi.org/10.1590/0104-07072015001032014

22. Soratto J, Pires DEP, Trindade LL, Oliveira JSA, Forte ECN, Melo TP. Job dissatisfaction among health professional working in the Family health strategy. Texto Contexto Enferm [Internet]. 2017 [cited 2018 May 06];26(3):e2500016. Available from: http://dx.doi. org/10.1590/0104-07072017002500016

23. Nogueira LS, Sousa RMC, Guedes ES, Santos MA, Turrini RNT, Cruz DALM. Burnout and nursing work environment in public health institutions. Rev Bras Enferm [Internet]. 2018 [cited 2018 Oct 31];71(2):336-42. Available from: doi: http://dx.doi. org/10.1590/0034-7167-2016-0524

24. Nora CRD, Zoboli ELCP, Vieira M. Ethical problems experienced by nurses in primary health care: integrative literature review. Rev Gaúcha Enferm [Internet]. 2015 [cited 2018 May 06];36(1):112-121. Available from: http://dx.doi.org/10.1590/1983-1447.2015.01.48809

25. Briese GP, Lunardi VL, Azambuja EP, Kerber NPC. Moral distress of community health workers. Cienc Cuid Saude [Internet]. 2015 [cited 2018 Oct 31];14(2):1035-42. Available from: http://dx.doi.org/10.4025/cienccuidsaude.v14i2.17696

26. Cardoso CML, Pereira MO, Moreira DA, Tibães HBB, Ramos FRS, Brito MJM. Moral distress in family health strategy: experiences expressed by daily life. Rev Esc Enferm USP [Internet]. 2016 [cited 2018 Oct 31];50(n.esp):086-092. Available from: http://dx.doi.org/10.1590/ S0080-623420160000300013

27. Carvalho BG, Peduzzi M, Ayres JRCM. [Conceptions and typology of conflicts between workers and managers in the context of primary healthcare in the brazilian unified national health system (SUS)]. Cad Saúde Pública [Internet]. 2014 [cited 2018 May 06];30(7):1453-1462. Available from: http://dx.doi.org/10.1590/0102-311X00134613 Portuguese. 